\title{
Why Teach Aviation? \\ A Snapshot of the Motivations and Influences Associated with the Careers of Professional Pilot Program Faculty
}

\author{
David Carl Ison \\ Rocky Mountain College
}

\begin{abstract}
The purpose of this study was to identify the motivations and influences that affect the decision of a sample of individuals to enter careers as professional pilot educators at the collegiate level. Six faculty members at four year, University Aviation Association member institutions were selected to participate in the study. Three individuals had a civilian background while the other three followed a military career path. Civilian faculty followed more varied career paths while those of military faculty were more structured. Civilian faculty pursued higher levels of education more for personal interests while military faculty did so due to expectations in the service. Familial and mentor support were both cited as important influences in most cases. The majority of faculty did not directly pursue a career in the professoriate but instead found their way to the occupation in a variety of ways. All but one faculty member were happy with their decision to enter higher education.
\end{abstract}

\section{INTRODUCTION}

\section{Overview of the Study}

From 1940 to 2009 , there has been substantial interest in higher education faculty in the United States. The seminal work of Wilson (1942), followed by studies by Finkelstein (1984) and Reybold (2003), investigated the overall attributes of the U.S. professoriate. More specific data on this group has been collected via large scale surveys including the National Survey of Postsecondary Faculty (NSOPF) conducted by the Department of Education (National Center for Education Statistics, 2006) and the Higher Education Research Institute Faculty Survey (2004). Several studies have been conducted on faculty in specific subject areas (Ison, 2009; Reybold, 2003; Fleet, Rosser, Zufall, Pratt, Feldman, and Lemons, 2006) and those of particular demographic attributes (Conley, 2005; Cross, 1991).

The goal of all of these aforementioned research studies was to better understand faculty through a collection of educational, occupational, and demographic distinctions. While these investigations have lead to a large database of information on individuals serving as faculty, what is much less understood is "[w]hat attracted them to faculty work? When did they decide to pursue academic careers? [And w]hat people and experiences were most influential in their decisions to become professors?" (Lindholm, 2004, p. 604).

According to Lindholm (2004) "there has been much written on how personal and environmental factors shape people's career choices [....] Very little theory or research, however, has focused specifically on the vocational development of college and university professors," (p. 603). The dearth of data on the motivations and influences associated with faculty career choice is problematic because "the answers to these questions are especially important given that projected increases in student enrollments coupled with widespread faculty retirements over the next decade will create a need to recruit large 
numbers of new faculty," (Lindholm, 2004, p. 604). What is more concerning is that even less data exists on the career choices of postsecondary faculty in specific subject areas. One such specialty in which a gap in research exists is professional pilot education. The only recent studies on this faculty cohort focused solely on the collection of occupational, educational, and demographic features of the group (Ison, 2009; Johnson, 1999).

Because aviation higher education has assumed an ever-increasing role in the production of aerospace industry professionals as the U.S. military, previously a major supplier of such individuals, has faced cutbacks while at the same time the industry, in general, has continued to grow, this lack of research is distressing (Echaore-McDavid, 2005). Industry expectations for highly qualified employees to operate and to manage increasingly complex aviation technologies has placed even more of a burden on aviation higher education to produce a workforce with these features (Brown, 2007; Echaore-McDavid, 2005; Hansen \& Oster, 1997; Baty, 1985).

Further information on professional pilot program faculty is needed to supplement existing data in order to best understand these individuals. To fully comprehend the nuances associated with professional pilot educator careers, it is necessary to explore what influences and motivates individuals to pursue careers within the professional pilot education professoriate. This information is critical to aviation program and general higher education administrators in addition to current professional pilot program faculty and those considering pursuing such a career path. It may also assist in the recruitment of future faculty and the retainment of existing faculty.

\section{Purpose of the Study}

The purpose of this study was to determine the factors that might influence the career choice of the aviation professoriate among full-time professional pilot education faculty who are employed at fouryear, University Aviation Association (UAA) institutions.

\section{Research Question}

This study sought to answer the following research question: What are the factors that influence individuals to become professional pilot education faculty?

\section{REVIEW OF LITERATURE}

\section{Aviation Higher Education and the Importance of Professional Pilot Faculty}

Even in light of the cyclical nature of the aviation industry, flying remains a critical component of the U.S. economy. Further, the aviation industry continues, over the long term, to grow. According to the Bureau of Transportation Statistics (2008), revenue passenger ton miles more than tripled from 1981 to 2007. The number of passengers carried by U.S. airlines (in millions) has increased from 605,434 in 1997 to 811,593 in 2008 (Federal Aviation Administration, 2009; Federal Aviation Administration, 2001). General aviation has also expanded, with the number of active aircraft (in thousands) increasing from 192.4 in 1997 to 231.6 in 2007 (Federal Aviation Administration, 2009; Federal Aviation Administration, 2001). Along with these augmentations has come the need for more pilots and other aviation professionals even though the industry has suffered in reaction to the recession in the U.S. economy from 2008 to 2009 (Ross, 2009). 
In the past, the military was a major supplier of aviation professionals, however, due to cutbacks and retention efforts, aviation higher education has had to produce more of the workforce needs for the industry (Donoghue, 2008). More complex aircraft and navigation systems, along with the need for proper management skills to handle crew situations and flight operations, necessitate well educated employees. These requirements for a highly educated workforce have shifted the hiring preferences among professional aviation employers to those individuals who have a college education. Airlines and corporate aviation departments currently have a strong preference for pilots who have college educations (Brown, 2007; Echaore-McDavid, 2005).

Therefore a growing industry coupled with an increasing desire for workers within that industry to have a college education point to the increasing importance of faculty who will provide such an education. Seeking to understand what drives these critical individuals to become faculty is necessary to insure that industry and higher education stakeholders have the best information available to seek out new faculty, to guarantee an adequate supply of future faculty, and to retain those who are already teaching.

\section{Faculty Career Motivations and Choices}

\section{Theoretical background of career motivations and choices.}

A significant amount of research has been conducted on the motivations and choices associated with the selection of career or vocation. Robinson, Murrells, and Marsland (1997) defined a career as "paid work and often implies continuous commitment to employment and progression through a series of hierarchical positions in an occupation" (p. 603). Expanding on this description, a career is also the "world of work" with horizontal and/or vertical mobility (p. 603). From these investigations into career motivations and choices have arisen a plethora of theories. Some theories assume a defined decision about what vocation to pursue that individuals make at some point during their life. Another take on career choice is that it is "less [of an] outcome of a single choice and more as an evolving sequence over a lifespan" (Robinson, Murrells, \& Marsland, 1997, p. 603). Yet another perspective is that "career patterns were determined not by individual choice, but by the extent to which they were enhanced, limited, or determined by features of the social structure" surrounding the individual making such a choice (Robinson, Murrells, \& Marsland, 1997, p. 603).

Other theories focus more on the concept of a "fit" between an individual and a particular vocation while others point to a more conscious choice that an individual might make to enter a specific career line. Holland's Theory of Careers builds upon his research on personality. According to Holland and Gottfredson (1976), workers fit into one of six personality types who have preferences for certain work environments. Holland (1997) stated that, although persons may exhibit traits of more than one personality type, they predominately react consistently enough to allow them to be categorized into one primary type. These types are realistic, investigative, artistic, social, enterprising, and conventional.

Weinrach and Srebalus (1990) describe each typology noting that realistic types prefer using machines and tools. An example career of a realistic type would be a machinist. Investigative types are analysts an example of which is a scientist. "Artistic individuals tend to be expressive, nonconforming, original, and introspective. [...] Decorators and musicians are artistic types" (p. 42). The social personality type seeks to help others. Teachers typically fall into this type (Johns Hopkins University, n.d.). The fifth type, the enterpriser, "manipulate others to attain organizational goals or economic gain. 
[...] Salespeople, office managers, and lawyers are enterprising types" (Weinrach \& Srebalus, 1990, p, 42). The last type, the conventionalist, "enjoy systematically manipulating data, filing records, or reproducing materials. [...] Secretaries, file clerks, and financial experts, are conventional types" (Weinrach \& Srebalus, 1990, p, 42).

According to Holland (1997), there are six types of environments that correspond to the aforementioned personalities. The most common arrangement is that an individual will migrate towards the environment most fitting to their personality. Thus, an artistic type would most likely choose work in an artistic environment. This is a logical conclusion because as more persons of a particular type come together in a work environment, the more that environment will replicate the sentiments of those working within it. There are, of course, exceptions as certain personalities do have psychological commonalities with other types. Finally, the behavior of a worker "is determined by an interaction between personality and environment" (Holland, as cited in Weinrach \& Srebalus, 1990, p. 41).

Roe's theory on career choice recognizes the innate response of individuals to their hierarchy of needs as described by Maslow $(1954 ; 1948)$. Roe and Lunneborg (1990) described eight occupational groups in which persons fall: service, business contact, organization, technology, outdoor, science, general culture, arts and entertainment. Service oriented individuals involve "a situation in which one person is doing something for another" (Roe \& Lunneborg, 1990, p. 71). Business contacts are similar to Holland's enterpriser where persuasion is a key element of the occupation. Organization types are best described as white-collar. Technology involves production and is much like Holland's realistic personality. Outdoor somewhat speaks for itself, where individuals prefer things such as farming or forestry. Science persons are those who are "primarily concerned with scientific theory and its application under specified circumstances other than technology" (Roe \& Lunneborg, 1990, p. 71). Among those considered in the category of general culture, "[i]nterest is in human activities, rather than in individual persons. This group includes occupations in education, journalism, jurisprudence, the ministry, linguistics, and the subjects usually called the humanities" (Roe \& Lunneborg, 1990, p. 71). Because of the crossover that may exist among educators at different levels, namely postsecondary faculty, such persons may be hard to distinguish between science and general cultural types. Arts and entertainment persons use their "special skills in the creative arts and entertainment" and perform in a capacity much like Holland's artistic individuals (Roe \& Lunneborg, 1990).

Within each of these occupational personality segments, Roe and Lunneborg (1990) noted that there are six levels at which an individual may work. The highest levels were the professional and managerial, which were followed by the semiprofessional and small business, skilled, semiskilled, and the unskilled. Overriding all of these concepts are five general "origin[s] of interests and needs" (Roe \& Lunneborg, 1990, p. 74) of each person. These include:

Genetic inheritance [...] limits. [...] The degrees and avenues of development of inherited characteristics. [...] The pattern of development of interests, attitudes, and other personality variables. [...] The eventual pattern of psychic energies, in terms of attention-directedness. [... And t] he intensity of these needs and their satisfaction (Roe \& Lunneborg, 1990, pp. 74-75).

Building on the premise of need fulfillment, Astin (1984) found that work is important to individuals because it provides for this fulfillment. Astin (1984) stated that work provides for survival needs in terms of the economic outcomes provided by work which bring forth the required food, shelter, clothing, and 
health. Pleasure needs are satiated through work activities and the intellectual/emotional pleasure coming from the performance of tasks such as problem solving. Contribution needs are fulfilled by the feelings of helping others or participating with others. Self-worth and self-esteem sprout from the interactive fruition of subordinate needs. Further, socialization, expectations and opportunities influence how an individual goes about satisfying their needs. The outcome of career choice is dependent upon what one feels they can do, what jobs are available, and how each available option fits into need fulfillment.

Krumboltz's Theory brings together many of these concepts into a more parsimonious explanation of career decision making. This theory is built upon the foundations of social learning. Social learning is brought forth through direct contact with positive or negative experiences, immersion experiences in which an individual is in close contact or within a particular environment associated with future work, and through experience of others (Mitchell \& Krumboltz, 1990). Mitchell and Krumboltz (1990) stated that the premise of this particular theory hinges upon three components: genetic endowment/ability, environment, and experiences. Although this theory is, on the surface, simpler, Krumboltz offers a complex means to sketch the career decision making process along with the various inputs necessary to reach such a decision over an extended period of time.

Super (1973) provided what is probably one of the most comprehensive summaries of the concept of vocational development. Super (1973) found that there are ten components of career choice:

- People differ in their abilities, interests, and personalities.

- They are qualified, by virtue of these characteristics, each for a number of occupations.

- Each of these occupations requires a characteristic pattern of abilities, interests, and personality traits $[\ldots]$.

- Vocational preferences and competencies, the situations in which people live and work, and hence their self concepts change with time and experience $[\ldots]$ making choice and adjustment a continuous process.

- This process may be summed up in a series of life stages characterized as those of growth, exploration, establishment, maintenance, and decline [...].

- The nature of the career pattern [...] is determined by the individual's parental socioeconomic level, mental ability and personality characteristics, and by the opportunities to which he is exposed.

- Development through the life stages can be guided, partly by facilitating the process of maturation of abilities and interests and partly by aiding in reality testing and in the development of the self concept.

- The process of vocational development is essentially that of developing and implementing self concept $[\ldots]$.

- [This] process [is one] of compromise between individual and social factors [...].

- Work satisfactions and life satisfactions depend upon the extent to which the individual finds adequate outlets for his abilities, interests, personality traits, and values (Super, 1973, pp. 262263).

In summary, a range of theories have been formulated on how individuals select a career as well as what motivates them to make such choices. Among these suppositions it is clear that there are certain fundamental commonalities. For one, it is recognized that individuals have certain preferences or traits. Another is that occupations tend to attract individuals with specific traits. Also, there are external factors that tend to influence the decision process. As a final point, worker satisfaction in their career selection is related to the compatibility or match between their traits and those naturally found within a vocation. 


\section{Faculty-specific motivations and choices.}

There have been a number of studies that have been conducted to investigate the motivations and career choices made by higher education faculty utilizing the theoretical principles outlined previously. According to Austin (2002), an "[i]ndividual's understanding of the faculty career begins with the graduate school experience or even earlier, not with the first faculty position" (p. 96). This leads to "anticipatory learning" i.e. individuals take on attributes of those who are currently in the position(s) that they seek. Clark (1987) noted that as potential faculty progress through the grooming stages of the preprofessoriate, individuals "assume identities that define and steer them for years and, often, for a lifetime of work" (p. 187).

Lindholm (2004) purported that faculty make two independent decisions that lead to the career choice of the professoriate: the choice of discipline and the choice of academic versus non-academic career paths. Finkelstein (1984) also found that faculty make these two critical decisions. Logically, the choice in discipline is most often chosen before exiting college, though it is possible that individuals may return to gain the needed education in a different major or subject at a later point. Choice to enter academe most often occurs at some point beyond the baccalaureate, although some individuals focus in on an academic career before completing their bachelor's degree.

Baldwin and Blackburn (1981) reported that "[p]rogress in one's career is undoubtedly stimulated and qualified by the interactive effects of internal and external forces" (p. 602). Examples of these influential forces are offered by Reynolds, McCullough, Bindixen-Noe, \& Marrow (1994): formative experiences (family, socioeconomics), personal characteristics (age, gender), professional characteristics (occupation, status), and perceived reward system. Finkelstein (1984) investigated faculty career influencers and found that the primary motivation could be traced to intellectual factors, e.g. desire for research, and the second was the encouragement from a mentor who frequently is a faculty member. Neophyte faculty tend to be drawn more by the former motivation.

The issue of "happenstance" also plays a role in the pursuit of academics - simply being in the right place at the right time - sometimes connects individuals with faculty positions. However, this is less likely among larger, prestigious research universities where prospective faculty need a proven record of publication, a terminal degree from a well-respected institution with an esteemed faculty advisor. Another critical component was identified by Althauser and Van Veen (1995). The career of an individual is subject to the "link between structural features of the labor markets and the socioeconomic attainment of individuals" (p. 91). Thus market forces must be favorable to allow entrance into available positions.

Reybold (2003) conducted a study in which a number of faculty were interviewed concerning their transition from doctoral student to academia. Instead of being some specialized procedure or ritual, Reybold (2003) stated that the "apprenticeship into the professoriate is tacit, embedded in the everyday activities and practices of their professional training milieu" (p. 235). Reybold (2003) described five core archetypes of how students/apprentices are transformed into faculty. These findings appear to align with other research on career choice both inside and outside of the professoriate.

The first embodiment of faculty pathways is the anointed:

For the anointed, the doctoral program is a formal apprenticeship toward the professoriate, characterized by one participant as an enticing "inside track" to success in the academy. Generally initiated by a faculty mentor, the apprenticeship usually focuses on research and publication within the mentor's area of expertise. Interestingly, this mentoring relationship typifies the student's membership and acceptance into the field. The anointed devotes considerable time and energy to the primary professional goal of establishing and maintaining a relationship with the mentor; for the student, this relationship symbolizes a developmental affiliation with the field (p. 240). 
These individuals tend to be more concerned with research agendas as opposed to teaching. Also, the anointed types prefer to have regular, supportive input of faculty during doctoral studies particularly in the dissertation phase. Faculty mentors of the anointed may help interest the individual by inviting them to participate in research, or providing extended assistance in an individual's research interests (Reybold, 2003, pp. 241-243).

The next model, the pilgrim, enters the professoriate via a carefully planned path:

This plan is strategic, concentrating on the accumulation of academic experiences commensurate with a faculty position. Although focused around research productivity, some students also seek independent teaching experiences and even committee service at the college or university level. Accomplishments toward future faculty roles are often discussed in terms of "lines on my vita" or future tenure expectations. Faculty and mentors may be utilized as resources to accomplish these strategic goals, but any mentoring association between the student and a faculty member is more functional than relational (Reybold, 2003, p. 244).

Rather than leaning on faculty as heavily as the anointed, the pilgrim uses mentors as a reference resource. They also tend to try to build experience through deliberate knowledge building. For example, one interviewee began presenting research at conferences early in their "career" so as to build a more substantive curriculum vitae. The pilgrim takes extensive credit for their progression toward the professoriate (Reybold, 2003).

The visionary model believes that they are drawn to the professoriate for the need of social change:

These students characterize their future faculty position, particularly their teaching and research roles, as a forum for achieving social change or educational reform. In other words, faculty roles are vehicles for initiating and sustaining this vision, even to the point of sacrificing certain professional goals such as research productivity and, for some participants, tenure (Reybold, 2003, p. 245).

Visionaries tend to believe there is more to research and teaching. Namely, these are just means to an end, and that end is the furtherance of some grander agenda. Through their efforts in higher education, one interviewee desired to help rectify the oppression of women while another sought to amend common stereotypes. This type of individual does not value tenure as highly as the other archetypes (Reybold, 2003).

Reybold (2003) further describes the philosopher category as one who seeks the professoriate as:

... a personal quest for intellectual growth and enlightenment. The philosopher's goal is to encourage their students and colleagues toward their own quest for personal development. They idealize their faculty roles, even to the point of expressing a passionate emotional connection to the professoriate and academe (p. 247).

These individuals can be described as perpetual students. They also describe themselves as proponents of pleasant learning environments or of an advocacy approach to handling students and learning (Reybold, 2003).

Finally, Reybold (2003) described the drifter. This type of faculty member happens upon the professoriate: 
The drifter expresses no singular commitment to academe. For these doctoral students, the professoriate is neither an ultimate professional goal nor a penultimate bridge to some greater personal or social cause. Many are not sure they even want to be a professor; their odyssey may take them through the professoriate at some point in their professional migration, but it may just as well lead to a corporate position. So these students are keeping other career options open... just in case (p. 248).

These individuals appear to view their migration towards the professoriate as a result of luck or coincidence. They do not show the level of allegiance or desire as the other archetypes. Further, they appear to be the least confident of all types in their abilities as a faculty member (Reybold, 2003). Yet even though there are commonalities among faculty in career choice and motivations, it is necessary to recognize the differences that may exist across subject areas in order to insure an adequate supply of qualified instructional personnel (Lindholm, 2004). Thus is logical to investigate the unique attributes of faculty within individual subject areas.

\section{METHOD}

\section{Participants}

The population for this study comprised of 193 individuals that responded to a survey on aviation faculty conducted in a separate study by Ison (2009). These individuals were full-time, professional pilot education faculty that were employed at University Aviation Association (UAA) member four-year institutions. Non-random, purposive sampling was utilized to select individuals from this larger group. Berg (2007) defined this type of sampling as when "researchers use their special knowledge or expertise about some group to select subjects" (p. 44). As Gay and Airasian (2000) noted, "the primary focus in qualitative research is on identifying participants who can provide information about the particular topic [... thus] sampling in qualitative research is almost always purposive" (p. 139). This type of sampling was deemed most appropriate for the goals of the study.

Finley et al (2003), senior faculty at the University of Nebraska - Omaha (B. Bowen, personal communication, June 12, 2008), and senior faculty at the University of Nebraska - Lincoln (M. Grady, personal communication, July 21, 2008) recommended that faculty that had a broad spectrum of experience and qualifications be selected for participation in the interview component of this study. A further requirement mentioned by each of the aforementioned sources was that every effort must be made to select those who are most likely to provide the detailed and comprehensive description of all essential attributes. The findings of Ison (2009) discovered that aviation faculty follow one of two primary pathways to reach the professional pilot professoriate, the military and non-military. In consultation with four senior research faculty at the University of Nebraska - Lincoln (M. Grady, R. Joekel, B. LaCost, and D. Sanger, personal communication, October 15, 2008), a target of three military and three non-military faculty was set for the interview process. Equal numbers of individuals were selected, as the findings of Ison (2009) noted a near even split between military and non-military faculty. A larger list of potential interview participants was extracted from those who were part of the survey respondent pool that fit these constraints because not all of those who were selected were expected to be able to or agree to participate.

To evaluate the potential of individuals to provide rich descriptions of their careers and choices within those careers, information about potential interviewees were collected from their school websites. Further, peripheral information was used to choose these persons. For example, one of those selected for participation authored a widely used aviation textbook. Another had given a well received presentation at a recent University Aviation Association conference. One selectee gives public presentations and speeches on a regular basis both inside and outside of their aviation education job functions. Another participant is on an advisory board to an industry grouped that necessitates extensive writing and speaking 
engagements. One participant was the chair of one of the largest aviation programs in the United States and had an extensive background in leadership functions, as well as a broad ranging career in aviation. The remaining individual had extensive and impressive experience, academic achievements, and an established job history in aviation higher education.

Thus, each of these individuals had a varied set of backgrounds to give insight into why and how different persons choose to or simply ended up in aviation higher education. Moreover, it was apparent that the backgrounds of these individuals and the positions they have held and/or currently hold indicated they would provide substantive data.

\section{Interview Protocol}

A semi-standardized interview method was used to query the selected sample of faculty concerning their career paths, choices and motivations. This technique was chosen due to its improved flexibility over the standardized interview. Berg (2007) stated that the semi-standardized interview is:

- More or less structured

- Questions may be reordered during the interview

- Wording of questions is flexible [...]

- Interviewer may answer questions and make clarifications

- Interviewer may add or delete probes to interview between subsequent subjects (p. 93).

All but one respondent was interviewed via telephone. The primary reason for the use of telephone interviews was the geographic dispersion of the respondents. As Berg (2007) notes, this was an appropriate method when researchers need "the ability to reach widespread geographic areas at an economical cost" (p. 109). All interview sessions were recorded using a portable tape recorder.

Guidance on the development of the design of an interview study as well as the creation of individual questions regarding career choice and impetus was garnered from the literature. Ferony (1996) utilized interview questions that were open-ended, analytical, and generative. Data was recorded and transcribed. A sample of individuals was selected from a larger pool of participants which was meant to reflect the demographics of the population. The interview questions used were:

- What influenced the choice of teaching as a career?

- What caused you to become interested in teaching?

o What life events influenced this choice?

o What career experiences influenced this choice?

- What strategies were used to get into teaching? (p. 154)

Analysis was conducted in a methodical process. First, participants reviewed transcripts, then interviews were read through by the researcher, and finally, analysis was done at the paragraph, sentence and line level.

Horrace (1989) provided even more guidance on the types of questions to use to explore career choices and motivations. Questions used in this study explored the respondent's primary occupation, parental occupation, family status, educational background, transition (voluntary or involuntary or retired), point in life decision was made, long-term career goals, why did you choose teaching. Lindholm (2004) used a semi-structured interview process to secure faculty career data utilizing the following protocol: 
1. How is it that you came to work at (this institution)?

2. What attracted you to pursuing a faculty career?

3. When did you decide that you wanted to be a professor?

4. Were there particular people who were influential in shaping your career decision? If so, what effect did they have?

5. Did particular incident(s) or experiences influence your career decision? If so, how?

Additional guidance on question construction was adopted from Campbell (2006) and Dierberger (1998). Although the general questions offered by this research were quite similar to those in other studies, extremely detailed probes accompanying these inquiries offered a more focused and in depth investigation into the data sought. Furthermore, certain questions relied heavily on research concerning faculty conducted by Finkelstein (1984). For example, queries into the attributes of the parents of an individual, including occupational and educational histories allowed analysis in comparison to previous research. Other examples included investigations into family life and school experiences (Campbell, 2006; Dierberger, 1998). Also, Dierberger (1998) included a question concerning the Maslow (1948) need of self-actualization. This question was modified slightly and adopted to gain insight into highest level of motivation among faculty.

During the question development and construction process, individual queries were compared to career motivation and selection theory. Aspects of Super's (1973) theory such as parental influences and vocational experiences were built into the questions. The pursuit of data on work satisfaction is a measure of alignment of individual preferences and the field and position in which one works. These concepts were reinforced by Super's (1973) theory which of course is closely aligned with that of Maslow (1948). Work by both Baldwin and Blackburn (1981) and Reynolds, McCullough, Bindixen-Noe, and Marrow (1994) pointed to a need to investigate the internal and external forces that influence career choice. These aspects were included in the interview protocol. Further, questions were designed so that the archetypes of faculty career paths presented by Reybold (2003) were gleaned upon evaluation of interview responses. Questions also were designed to bring out responses that could typify individuals in relation to Holland's theory on career choice and alignments.

To insure quality data collection, an interview schedule was developed based upon the guidance in Berg (2007): "The specific ordering (sequencing), phrasing, level of language, adherence to subject matter, and general style of questions" (p. 99) were tailored to the fact that all panel members were familiar with aviation, higher education, and each had attained a graduate level education. Berg (2007) indicated that there were four primary question types: essential, extra, throw-away, and probing. Essential questions "concern the central focus of the study" (Berg, 2007, p. 100). The majority of the questions utilized in the study were of the essential type. Each such question was open-ended to prompt as much unbiased input from the individuals as possible (Finley et al, 2003).

Additional probes, those questions designed to "provide interviewers with a way to draw out more complete stories from subjects" were included on the schedule to assist the interviewer as necessary throughout the process. These items came directly from Berg (2007), as well as from other studies that utilized panel of expert interviews (Prochaska-Cue, 1988; Dolezal, 1991; Masse et al, 1998; Elit \& Otchet, 1999; Giacobbi, Jr., 2002; Finley et al, 2003; Finch, Begley, Sutherland, Harrison \& Collins, 2007).

Before beginning the interview process, the schedule was pretested. Berg (2007) stated that "the schedule should be critically examined by people familiar with the study's subject matter [... such as] other researchers" (p. 105). As suggested by Berg (2007), the researcher conducted practice interviews with the schedule to correct any noted problems. 


\section{Validation of the Interview Instrument}

Validity in the context of this qualitative context is the determination of "whether the findings are accurate from the standpoint of the researcher, the participant, or the readers of an account" (Creswell, 2003, pp. 195-196). This study followed the validation methods outlined by Kvale (1996) for each stage of the interview development and analysis process. During the design phase, significant efforts were undertaken to carefully and logically plan the methods based upon what was found in the research literature. Also, ethical concerns were a focus with special care to follow what Kvale (1996) describes as "a valid research design [that] involves beneficence - producing knowledge beneficial to the human situation while minimizing harmful consequences" (p. 237). While interviewing faculty participants, the "trustworthiness of the subject's reports" (Kvale, 1996, p. 237) was assured by recording the sessions. Interview integrity was augmented with procedures laid forth by the available literature.

Transcription was completed verbatim from the recording of the interview sessions assuring "valid translation" (Kvale, 1996, p. 237). To maximize the precision of the data, a professional transcriptionist was contracted. A confidentiality agreement was made with this individual to insure confidentiality. These transcripts were then confirmed by the researcher by comparing them to the recordings. According to Creswell (2003), reliability, known as the "stability or consistency of responses [...] play[s] a minor role in qualitative inquiry" (p. 195). Thus, respondents were given the opportunity to review their responses for accuracy. No discrepancies were reported within the interview transcripts.

\section{Procedure}

A group of six individuals was selected from the pool of participants who completed the survey instrument in a previous research study by Ison (2009). Three persons were selected from each of the primary pathways identified by Ison (2009), i.e. civilian and military. These individuals were contacted via email to inquire into whether they would like to participate in the interview process. Upon agreeing to participate, the researcher arranged for an in-person or telephone interview. Each interview session was recorded and then transcribed verbatim. Respondents were given the opportunity to check the transcript for accuracy of their inputs.

\section{RESULTS}

The results stemmed directly from the analysis of the interviews that were conducted with each of the six professional pilot faculty members. Initially, the findings were constrained within the responses to the interview questions. As the data was organized and coded using NVivo qualitative research software, specific topics emerged. The comments on each topic from respondents within the same pathway were grouped together. This allowed for the identification of commonalities within a pathway membership and simplified the comparison and contrast analysis with those who had taken the alternative career pathway. As the analysis of data progressed further, the interview, the literature review, and the applicable research question were used to direct the organization of the findings. Coded topics and concepts were then linked to the appropriate common subject areas.

The majority of the results lent itself to be organized in NVivo free nodes. The free nodes utilized were educational history, school experience, occupational history, decision to become a professor, actions taken to pursue a career in higher education, mentors, discouragement received, and an inquiry into what faculty might do differently. More complex topics were placed within NVivo tree nodes so as to separate

and organize the data. The tree nodes used were family and happiness with career choice. Subordinate within the family tree node were parents, relatives, and siblings. Within happiness with career choice, the general subject was subdivided to specifically extract if faculty believe that teaching was their "calling." 


\section{Civilian Faculty Responses}

\section{Occupational history.}

The occupational backgrounds of those civilian faculty were varied and circuitous. One common trait was that each faculty member reported that they had been involved in aviation for quite some time with individuals reporting flight experience of 28,31 , and 39 years. Two individuals had the rank of associate professor, with one working in aviation higher education for 5 years and the other 23 years. The other civilian faculty was a full professor and had been in aviation higher education for 21 years.

The first individual reported becoming interested in aviation in childhood then learning to fly in high school. This person graduated from college in 1973 and sought out a bush pilot position. When that did not become immediately available, this respondent went to airframe and powerplant (A\&P) mechanic school. Soon thereafter, this person fulfilled the dream of doing some bush flying by working with a mission-oriented aviation organization in Brazil. After a brief time this individual returned to the U.S. to finish the A\&P training they worked as a flight instructor and charter pilot in a large metropolitan area. Within a short period of time, a bush flying opportunity became available in Alaska. This individual reported some very interesting and unique flying experiences during this single season occupation. This included flying a tremendous amount of fish to and from remote and rugged parts of Alaska. Upon the end of the fishing season, this faculty member returned to flight instruction and charter work in a rural location. Following a downturn in the economy in the late 1970's this individual decided to pursue a spiritual career path and attended seminary.

Upon completion of this program, this individual wanted to better their career chances by pursuing an advanced degree. An agreement was made with someone at the school at which this person was interested in attending that would allow the person to go to school and do some flight instruction at the institution's flight department. After about a year of doing so, this individual was brought on as an assistant professor of aviation. From that point (1985) the individual has been a professional pilot educator in higher education.

The second interviewee noted becoming interested in aviation as a child after a positive experience with flying on a transoceanic flight. Formal flight training followed in college. Soon thereafter, this individual was flight instructing at a university flight program and then entered the aviation job arena as a corporate pilot. This individual served as a chief pilot, started three major flight departments including one for a Fortune 500 company. This individual flew internationally and gained experience in jets and turboprops. This respondent had a mix of managerial and flight duties at these different companies. Later, this individual was involved in consulting on an airport development project. This person had just had a child and around the same time the loss of their spouse played a critical part in them a career path change. From this point they began to pursue a career in higher education. However, this person still plays an active role in industry and reported being the liaison between the school at which this individual teaches and business aviation organizations.

The last individual had the most diverse career path and perhaps the most indirect in terms of flying. This individual entered the job market with an engineering degree over forty years ago. This respondent then worked in broadcasting for a few years and then decided to pursue an engineering-related occupation. This individual was initially hired by a major airline to do industrial engineering work. Due to escalating managerial requirements, this individual went back to get a master's of business administration degree (MBA) with emphasis on technical systems management. This individual also showed interest in law and pursued a law degree while continuing to work for the same major airline. 
Upon completing the law degree, this person was given more of a counsel-like position in the airline and began to work with flight crews. After being an employee of the airline for almost ten years, this individual became involved in flying through learning to fly outside of work.

This individual bought an airplane and began to fly with increasing regularity. This increased focus on flying also helped at work, boosting participation in flight-related incidents that involved arbitration. Happening simultaneously, this faculty member was operating his own aviation business that focused on flight training. Due to the close proximity of flight school business to a local higher education institution, this individual gained a relationship with the school. This turned into a 15 year stint in academics from classroom teaching to administrative duties. In 2001, this individual retired from this position and took a year off to do some travel. Immediately thereafter this individual re-entered higher education at a different institution and has resided there since.

The common thread among these faculty is the multitude of occupations that they held during their progression towards entering aviation higher education. Of course, each one found his or her way into flying differently, but two especially seemed to be destined for participation in aviation. As one of these respondents noted "I had my first airline flight on a 707 and then somewhere along the ride across the Atlantic Ocean and I told my parents 'I want to be a pilot.' [...] I don't know. You ask aviators why they like to fly. I don't know. It's just always been there." The other similar faculty showed dedication to aviation early in life:

I started flying in high school. I was, as far as I knew the only person in my high school that had a pilot's license. Between my junior and senior year in high school I went to the local airport and said I wanted to learn to fly and made a deal with them that I would work at the airport, pump gas, clip grass, and all that kind of thing but they would pay me off in flying lessons.

Even the remaining faculty member who did not seem as immediately drawn to aviation succumbed to influences of aviation peers to become involved in aviation. Surrounded by airline pilots, this individual was coerced to start flying. And from the quick adoption of flying it was apparent that this individual had simply had a delayed start and love for flying.

\section{Educational history.}

Civilian faculty reported a range of different degrees and subject areas in which these degrees were received. One respondent received a bachelor's degree in an aviation-related field 35 years ago. They then received a master's degree in divinity about ten years later. This was followed by an EdD in educational administration and adult higher education which was received one year ago. Another faculty member received the bachelor's 28 years ago in aviation management. A master's degree in aerospace education was completed three years later. This individual completed a PhD in leadership within the last year. The other civilian faculty member attained a bachelor's degree in industrial engineering 38 years ago. They then got an MBA four years later. They followed with a Juris Doctor degree four years after the MBA.

The completion of degrees beyond the bachelor's level appears to have been brought about by personal desires and motivations in addition to some posturing for academic careers. The individual who received the EdD, specifically did so to help improve held academic credentials viewing such an education as an inevitable requirement in higher education. The individual who pursued a $\mathrm{PhD}$ wanted something that could help this individual to improve this person's standing in both industry and in academia, to "bridge between the two worlds and have credentials across those both roads, and that's really what drove me to do it." The remaining faculty member pursued their master's and J.D. degree out of interest in the subject areas. The master's degree did seem to be helpful in improving the status of the individual in their workplace and both advanced degrees opened up opportunities within the workplace. 


\section{School experience.}

Faculty were asked about their experience with higher education as a student. Specifically, faculty were queried about performance in school and perceived difficulty of schoolwork. One faculty member admitted that as an "undergraduate, I had a lot more potential than my grades show. I had too good of a time." But at the advanced education levels this individual reported doing very well "so it is just probably a lot of just growing up and maturing." Similarly, another faculty member stated the undergraduate grades this respondent received were lower than they could have been, but in the case of this faculty member, the performance was blamed on distractions: "I ran out of money [....] I wasn't very focused as an undergraduate student and developed no study habits." But at higher levels of school the story was different: "[it] came fairly easy and I made really good grades." This was attributed to the fact that this individual "had settled down and had been out on [their] own, started working, developed the kind of habits to sit down at a desk for a pretty good while and read and study and write." The remaining faculty member reported finding school easy "all the way through."

\section{Decision to become a professor.}

Faculty reported several different ways they came to become a professor in professional pilot education. One individual stated that it was basically happenstance - this particular person originally intended to pursue one career path and ended up in aviation education:

Because once I started here, up until just recently if you wanted to work on a doctorate and you were a faculty member, you couldn't get your doctorate at the same university. In other words, I couldn't get a doctorate anymore and counseling kind of fell by the wayside, once they kept promoting me and whatever in aviation and I just never even took a class in counseling, because that was my original intention to work on a doctorate in counseling.

This faculty member reported having a philosophical shift after working in higher education for a few years: "Before I was a pilot who just happened to be at this institution of higher education and teaching and an educator, but later on after about 10 years I started thinking of myself as an educator who is a pilot."

Another civilian faculty member got involved in teaching in a more academically traditional way:

Actually beginning grad school I was approached while I was working on my master's to teach a ground school $[\ldots]$ and at that point they never had a graduate assistant instructor. Now they do it all the time. From $1981 \mathrm{I}$ became a graduate assistant instructor in their program teaching private ground school. That was my first taste of it and I found it quite interesting.

Additionally, the academic career was appealing for personal reasons:

That probably is what led me to in 1989 then go back to teaching for two or three years when I started my family and I enjoyed it, and that is probably what led to realizing when I needed to exit industry until my daughter got grown, that this was an avenue that I enjoyed. 
The remaining faculty member could not identify a particular point in their life at which this individual chose to enter aviation higher education. This respondent originally thought to teach in another subject area, but did state that there was an innate draw to teaching:

Ironically, I don't know if I decided I wanted to be [a professor], but certainly was very attracted to [college teaching] and figured that I would probably get there sometime [....] If you had asked me as a college kid I would have mentioned in there sometime and in fact I think some of the psychological career type placement testing when I was a senior in college, I think I may be interested. I could have seen myself teaching broadcasting in college.

\section{Actions taken to pursue a career in higher education.}

Two civilian faculty provided specific actions that were taken in pursuit of careers in aviation higher education. One noted specific academically-related action while the other took more of a practical teaching route. The former faculty stated that it would become necessary to pursue a doctorate to continue moving up in academia. The latter individual sought out aviation-related teaching opportunities and was located closely to a higher education institution with an aviation program thus this individual figured that the two would eventually overlap. Eventually this individual approached the local institution about working in their aviation department. The other civilian faculty member did not specifically prepare for entrance into higher education: "Well, I fell into this position, I suppose. I didn't really plan on it, in my case. I came up here not even to be part of the aviation program, I came up here to work on a different degree." However, this individual did eventually pursue a doctorate degree to gain academic credentials in order to better positioned in higher education.

\section{Influences from family.}

An inquiry was made into the influences that family had on an individual's selection of a career in aviation higher education. Specifically, probes were made to extract information about the parents, siblings, and other relatives. All civilian faculty respondents stated that they grew up in middle class households. The parents of two faculty members each completed college. Both fathers had received a bachelor's degree and one mother had received a master's degree. The remaining faculty member had a father who achieved a master's degree and a mother with an incomplete college education. One father worked as a medical technician, another was an active duty Navy surface warfare enlisted man, and the other was in the oil industry working in chemicals. Two faculty noted that their mother was a homemaker while they were growing up, while the other faculty member stated their mother worked regularly through their childhood. Two faculty had mothers that were at some point involved in education with both working as librarians.

All civilian faculty had brothers or sisters. One civilian faculty had an older brother that was in the military. Another faculty member had an older brother that was in the military and an older sister that is a college professor in English. The other faculty member had a larger family, three brothers, and ranked third in birth order. None of the brothers were involved in aviation or education. None of the civilian faculty stated that their siblings influenced their career choices.

When asked if relatives played a role in getting into aviation, all faculty reported someone who did so in their family lives. One faculty member stated "my uncle was in the Air Force and he took me for a ride when I was 12 years old and I said, oh, this looks like fun. And it stuck with me. I always kind of thought to become a pilot." Another reported a similar instance early in life. The other faculty member worked in and around aviation and was eventually drawn to flying through camaraderie. Two faculty members recognized that their mother's roles in education did have a minor role in influencing their affinity for 
teaching. Only one faculty member specifically reported being influenced by relatives to enter higher education:

My grandfather did teach college for his whole career [...] We would go there almost every summer and some Christmases and visit so I did have that kind of exposure into faculty life and especially for that era and that point in time that geographic location and was really the academic life right out of an old movie. Ivy covered halls, the faculty met everybody and called each other professor, ate dinner together and was really the kind of stereotypical image of academic life and for a kid going over there and getting into the basketball games and football games and stuff like that when we would visit, made a very positive connection.

\section{Mentors.}

All civilian faculty reported having multiple mentors along their pathways to the professoriate. One individual noted a specific individual as the primary influence in their academic pursuits: "watching him in the way he did things, the way that he talked, it was inspiring in and of itself." Yet others were also influential: "[the] chair of the department now, has been a rock all of these years. We have kind of just grown up in the program together." One of the other faculty stated that "I had mentors all around. My mentors have always been someone one or two rungs above me in industry." This individual reported having a specific mentor currently who is on the board of directors of a large business aviation organization. This faculty member stated that they continue to seek inputs from all mentors encountered: "I have had these mentors forever."

The remaining civilian faculty member mentioned a wide range of mentors encountered along the way. This individual mentioned a father of a friend that helped steer general life pursuits. Another mentor was a boss early along the individual's career and suggested pursuing an advanced education. Finally, this faculty member noted that there was one person in particular that was "the most influential long-term and probably to some extent toward the college [teaching career....] He and I were pretty close. He gave a lot of career advice and he was one that had first started suggesting teaching kind of things."

\section{Discouragement received.}

Only one individual reported any kind of discouragement or resistance when in pursuit of aviation higher education. The majority of this seemed to stem from the fact that this faculty member was a successful woman who was clearly a minority, breaking into aviation at a very early stage in the assimilation of women into the industry:

Well, you know I came into business aviation in 1982 [...] if you know the history of that time, very, very few women [were in aviation.] I was the first woman pilot [at a particular entity] in 1983 and so I was in that batch of first corporate women that literally kicked open a lot of doors, and so yes there were obstacles if you can imagine the early 1980's, the South, there were a few people that didn't think I needed to be there.

\section{Happiness with career choice.}

Two civilian faculty members stated they were happy with their career choice in aviation higher education. "No question about it, sure, yes." "Yes. I have enjoyed it. It has been a good ride, a good trip." The other faculty member said "No. I think academia is incredibly frustrating." When probed about whether they would take part in aviation higher education again they said no. However, they did mention that if they could be a dean or other academic administrator, a position they feel could impart more change, they would consider possibly participating in aviation higher education. 
When civilian faculty were asked if aviation higher education was their calling, only one stated that it was. Of the remaining two faculty, one clearly did not believe that aviation higher education was their calling while the other was less exclusive:

I don't know if I would go that far. I have had trouble my whole life with the whole concept of calling.[...] I think it is something that I definitely reached a decision to do and it was a firm decision. It wasn't just the path of least resistance but I'd be skeptical of the term calling.

\section{Inquiry into what faculty might do differently.}

Faculty were then asked if they would do anything differently in choosing the professional pilot education career path. Only one stated they would most likely have avoided becoming involved in academia. In fact, this individual already had some plans to exit aviation higher education: "I have actually started a nonprofit [...] this summer and am actually truthfully probably working my way back to industry." The remaining two faculty were satisfied with their paths to their positions. One remarked "the way it worked out was probably best." When the other faculty was asked if this individual would change anything along their career path, this person stated "my gut reaction is to say no [...] there is not anything that I sit here and go home each day saying, man I wish I had done this or done that."

\section{Military Faculty Responses}

\section{Occupational history.}

Individuals who served in the military had a fairly methodical career progression. Two out of the three respondents entered military service through participating in Reserve Officer Training Corp (ROTC) programs in college. The final respondent entered the military through a U.S. military academy. All military faculty that participated in this part of the study had served in the U.S. Air Force. Also, each individual retired from the military meaning they had served for an extended period of time. The length of flight experiences displayed were 27, 33, and 39 years. These individuals have been involved in higher education five and a half, six, and five years respectively.

One military respondent entered the Air Force so this individual would not be required to follow the family business. This respondent almost immediately became a pilot after graduating from college and continued in that capacity for 20 years. This faculty member flew a large tactical nuclear bomber for most of their time as a pilot. This respondent then became involved ROTC bringing this person in contact with a higher education campus. Upon retirement this individual was located at a campus where there was a new aviation program. This individual exited as a colonel. This faculty member was asked to help in the process of growing the school. This respondent reported being an associate professor and the program coordinator.

The next military faculty spent 21 years as an active duty Air Force pilot and served in a wide range of duties. This individual was a pilot instructor early on. Following this duty, this individual flew large transport jet aircraft soon followed by becoming a classroom instructor at the U.S. Air Force Academy. This respondent eventually ended their career flying very important personnel (VIP) in transports. This individual exited as a lieutenant colonel. Following retirement from this duty this individual became director of the aviation program at a small college and reported having reached the associate professor level.

The last military respondent entered the Air Force through ROTC and then spent 23 years in the service. While in the service this individual had a mix of flying and administrative duties although these 
were all related to flying. This faculty member progressed through the following duties: Director, Transportation, Military Airlift Command (MAC); Deputy Group Commander, Air Transportation, Airlift Group (MAC); Commander, Aerial Port Squadron (MAC); Commander, Airlift Control Element (MAC), C141 Aircraft Commander qualified; Manager, Air Transportation Plans and Programs Division (MAC); Commander, Base Transportation Squadron Aerial Port Operations Officer; Chief of Safety, VC140 Aircraft Commander qualified; Flight Safety Officer,. C141 Aircraft Commander/Instructor qualified; and Squadron Administrative Officer, C123 Aircraft Commander qualified. This individual exited as a colonel.

Following service in the military, this individual entered the airline world as a pilot progressing through the following duties: Assistant Chief Pilot, A320 Captain qualified; Manager Line Operations, B737 Captain qualified; Line Assigned Captain, B737 Captain qualified; and Flight Safety Manager/Investigator, B737 Captain qualified. Upon leaving the airlines, this individual became an adjunct faculty member at a large university. This individual eventually gained a full-time position and has resided there since. This faculty member reported being the chair of the aviation department and held the rank of assistant professor.

The responses offered by military faculty did show that these individuals tend to follow structured occupational paths to reach aviation higher education. This should not necessarily be surprising due to the structure of military life and careers. Also, these individuals did not really talk about flying in terms of a destiny but seemed to be an assumption necessitated by being associated with the Air Force.

\section{Educational history.}

Much like the occupation paths, military faculty have stable educational histories which were characterized by a bachelor's degree in a variety of fields followed by a master's degree that was attained under the strong encouragement by military rank protocols. Only one individual had completed a degree beyond the master's level and the remaining two faculty were not pursuing such further education.

One military faculty member received a bachelor's in agricultural business 34 years ago. During service in the military this individual received a master's degree in aeronautical science. This degree was received 21 years ago. No further education has been or is being pursued. The next military faculty member received an undergraduate degree in mechanical engineering in 1982. Ten years later this faculty member received a master's degree in engineering. No further education was received or is currently being pursued by this individual. The remaining military faculty member received a bachelor's degree in secondary education, a major in biology, and a minor in chemistry in 1967. This individual then received a master's of arts degree in management in 1975, followed by an associate's degree with a specialty in management in 1979. The associate's degree was attained to better serve in a teaching capacity at the school at which it was received. Lastly, this individual just received a $\mathrm{PhD}$ in business administration in 2008.

It was made clear by all three individuals that the pursuit of a master's degree was a requirement for promotion and favorable assignments while in the military. Considering that these individuals retired at the rank of lieutenant colonel or colonel, it was not a surprise that they pursued advanced education. At the same time, it appeared that the achievement of this level of degree precluded any motivation for further education in the military. The one individual that did attain a doctorate did so to position themselves more favorably in academia. 


\section{School experience.}

Military faculty reported mixed results for their experiences as a student in higher education. One individual did not feel as though school was very challenging but "[I] didn't get very good grades in college because [they] had a ROTC scholarship and had pretty much already selected my career path and I was kind of meeting the minimum requirements." This individual did not report having any trouble succeeding in graduate education. Another military faculty member stated that in "undergraduate I did very well, you know, I was probably a B average [...] but I worked two jobs." At higher levels the performance by this individual was more impressive: "I did a lot better at the master's degree because I got a 3.66 [GPA ...] and for the PhD I got a 4.00 [GPA]." The remaining individual reported that throughout school "I was a good student. I did well. It seemed to come fairly naturally."

\section{Decision to become a professor.}

Two of the interviewed military faculty made it evident that they had been interested in teaching for quite some time. Interest in education, in particular higher education, came early for these two individuals. One individual stated that upon being exposed to the world of higher education teaching, this person seemed to have found a good fit: "I can remember saying to a coworker, I feel as though I discovered what I am, I am a teacher. Whether it is in an airplane or in a classroom I really like teaching." Similarly, the related faculty member said:

Well I've been teaching off and on, because remember I went to college to be a teacher and actually did teaching in college at a high school okay. And then you got to remember I went in the Air Force and when you go in the Air Force usually you have an opportunity to instruct, which I did, so I was able to flight instruct.

The remaining military faculty member appeared to flow into higher education less as a personal pursuit and more out of being in the right place at the right time. This faculty member also discovered teaching as a viable option later in life. When asked about when they decided to enter higher education this individual remarked "the day I retired." This respondent expressed plans to enter the airline world as a pilot but did not due to the September $11^{\text {th }}$ terrorist attacks:

So I decided I was going to be an airline pilot and essentially was being considered for interview with [a major airline] and 9/11 happened. So that one went bye-bye and then I fell back into the I think I want to be a professor and a job opened up.

\section{Actions taken to pursue a career in higher education.}

When asked about the specific actions taken to pursue a career in aviation higher education, each military faculty noted actively performing some kind of preparatory task to position themselves for this career. One faculty member pursued the required civilian licensure so they would be qualified to be a versatile aviation faculty member:

Well, I went and got, let's see, I went and took a bunch of FAA writtens because I wasn't properly, didn't have the CFI rating and frankly hadn't done much flying [....] And then in order to be qualified for this job, I had to have a minimum of a ground instructor. I went and got advanced and instrument ground instructor ratings.

Another faculty member stated that while pursuing academic qualifications, i.e. advanced education, due to the needs of a rising military officer, it was realized that other benefits came at the hands of such pursuits: "the accumulation of degrees was actually the credentialing needed for the next job opportunity, 
promotion opportunity, success opportunity." The remaining faculty member sought out a teaching position at the Air Force Academy as interest in teaching grew. While this faculty member did not know when a decision was made to get into higher education as a long term career, this individual was confident it would happen at some point in life.

\section{Influences from family.}

Military faculty provided insight into a mixture of different family backgrounds. All three respondents stated that their fathers were active duty military personnel at some point in their lives. This was noted to have played some role in their pursuit of a career in the military. Two military faculty reported that their fathers played a significant role in influencing them to pursue aviation. All fathers had some college education, but only one had completed a four year degree. Among the mothers of military faculty, all were received some college education with two having completed a bachelor's degree. The two mothers that had completed four years of college were also school teachers while the remaining mother was a nurse. One mother was a stay at home mother, while the other two worked. All reported enjoying a middle class upbringing.

All military faculty reported having siblings. One stated that being the middle child with an older sister who now runs a campground and a younger brother that works at an airport but "he has no interest in flying." The next faculty member had two brothers and this individual was the middle child. Only one of these brothers was involved in an aviation-related job field. The remaining military faculty member was the oldest of two boys. Their brother was not involved in education or flying. None reported being influenced in career decisions by their siblings.

As far as other relatives that influenced military faculty into pursuing aviation and/or higher education, there was a variety of responses. One faculty stated that there were absolutely no relatives that played a role in this process, although this individual indirectly related distaste for continuing in the family legacy of agriculture. Another faculty member reported having quite a few relatives in the military and got to know the Air Force well through the eyes of these family members, causing a leaning towards aviation. This individual hinted that maternal involvement in education may have had some influence on being inclined to enjoy that type of career. The remaining faculty member painted a detailed picture of relatives that guided this individual into higher education:

I have held teaching in very high esteem. Scattered throughout my family past is a lot of educators and I always thought teachers were noble. My maternal grandfather [...] was fairly involved in my life, all things considered. He had been a superintendent of schools and a professor of education at [a large university in the West...] My mom's sister's career was a classroom teacher in [the Northwest], elementary, learning disabilities. My wife, when we were first married, she was in public education, special education teacher.

\section{Mentors.}

Two out of the three military faculty noted that mentors played an important part in guiding these individuals along their paths to higher education. One stated that a prominent member of the University Aviation Association "helped me a little bit and kind of pointed me in the right direction to make myself qualified for a potential job, and after I was hired he helped me somewhat before he left." The other mentored faculty stated there were many peers that acted as mentors but one person specifically helped more than the rest: "I admired him and he filled my head with a lot of good stuff about the nobility of education, the importance of integrity in the classroom." The remaining military faculty member reported more self-guidance taking matters into one's own hands to find their way into higher education. 


\section{Discouragement received.}

Only one military faculty respondent encountered any kind of negative sentiment towards choosing a career in aviation higher education. Friends questioned why this individual would choose such a career in light of the potential earnings and prestige in the airline world:

As I was getting ready to retire from the military many of my peers who were also retiring [....] At the time it was easy to get a good airline job, United, Delta, FedEx, they were all hiring [..... My peers] looked at me a little bit sideways and said, what are you doing? Oh yeah, you're one of those brainiac academic types.

\section{Happiness with career choice.}

All military faculty reported that they were happy with their career choice as professional pilot educators. One faculty member acknowledged the importance of passing the torch of knowledge to the next generation of pilots: "I really love aviation and it is a way of giving back to that profession by doing my best to make a better breed of younger people who will carry on." Another military faculty stated very similar sentiments:

How often does the person in their career have the opportunity to give back to the next generation the experience level gained so they don't have to repeat some of the same errors. That's personally rewarding as well as educationally rewarding.

The remaining faculty stated that teaching was critical to their happiness in the world of work: "When I thought what I liked best about my career, it was the teaching. Sure I liked the flying [...] but I think overall most satisfying part about it is mentoring [....] That's very much what education is."

Faculty were then directly asked if they felt as though teaching was their calling. Two responded positively. "I would. I absolutely would. [...] I very much think it is a calling." "Oh yeah. Absolutely." One faculty member said it was not. "No, I wouldn't consider it a calling. I would consider it a profession that you are in."

\section{Inquiry into what faculty might do differently.}

When asked if they would do anything differently, military faculty stated that they would not change their decision to become professional pilot educators. One said "in retrospect, I wish I would have started earlier." Another talked about wanting to have worked on academic qualifications earlier in life: "In theory, I would have like to squeezed in a PhD along the way." The other faculty member would do it all the same way again noting the great satisfaction received in doing the job: "one of the personal rewards is to be able to take your work experience and your background and be able in an educational form to use that to instruct subject matter for those who follow you."

\section{Comparison to Previous Research}

\section{Faculty motivations and archetypes.}

Faculty interview data was compared to previous findings on faculty career motivations and choices. Robinson, Murrells, and Marsland (1997) stated that career choice was a life-long, ongoing process. This was found to be true among all types of professional pilot faculty. Interview findings also were aligned with Holland's (1997) premise that there is a fit between the individual and their vocation. Professional 
pilot faculty appeared to be a mix of scientific and social types seeking both research activities and interaction with people. Naturally, as Holland (1997) surmised, persons with these attributes would be drawn to environments that are suited for such tastes. Clearly, institutions of higher education provide this type of environment. The one faculty member who stated not being particularly happy with the career choice of aviation higher education appeared to fit the conventional personality and favored a similar environment. This conflicts with the environments most closely associated with higher education: the social and scientific. This could help explain their dissatisfaction.

Need fulfillment, as described by Roe and Lunneborg (1990) also could be seen in the interview responses. All faculty showed that they gained pleasure from performance of problem solving and learning tasks as well as through helping others. These actions and desires fulfill the pleasure and contribution needs. Social learning was seen in many of the interview responses. Immersion in the environment and with the people working in the field helped influence not only some faculty member's choice to follow a career in aviation but also higher education.

Also the interplay of ability, environment, and experiences appeared to be a factor. All of the faculty interviewed had academic abilities that had made them successful in a variety of scholarly pursuits. Their environment influenced their choice to pursue their aviation and higher education careers, for example, one faculty was engrossed in the airline world while another was exposed to teaching opportunities as part of their job functions. Experiences were wide ranging in terms of flowing into higher education stemming from positive influences from peers, success in flying, and through fulfillments brought about by getting some familiarity with teaching and the academic life. The idea of a good fit of career and individual is reinforced with Super's (1973) theory which alludes to the need for individuals to have an adequate outlet for their skills, interests, personality, and values. The faculty members that reported they were most satisfied and had found their calling in aviation higher education appeared to fall into the confines of this theory.

Austin (2002) noted that faculty, specifically, often experience anticipatory learning where individuals migrate towards the attributes of those within their career choice. Most of the interviewed faculty did seek the credentials and experiences that would suit them best for a career in academia. Professional pilot faculty seemed to be influenced by many, if not all, of the factors identified by Reynolds, McCullough, Bindixen-Noe, and Marrow (1994). Formative experiences, such as family, played a prominent part in shaping the careers of aviation faculty. Personal characteristics also played a role, as one individual encountered challenges that others did not because of their gender. The professional characteristics definitely drew individuals into aviation higher education. All interviewed faculty were pilots in some capacity and they all were involved in some sort of flight instruction which is a potential grooming avenue for entrance into educational pursuits. The perceived reward system also was a factor. Explicitly, one faculty member saw what the academic life might be like and was immediately drawn to it.

Other factors identified by Finkelstein (1984) were shared by professional pilot educators. One was intellectual related where there is clearly academic/scholarly interest on the part of the faculty member. Mentoring was also identified as playing a big role in the shaping of faculty career paths among aviation faculty interviewed. Another occurrence observed by Finkelstein (1984) that occurred among aviation faculty was that of being in the right place at the right time. At least two faculty reported such alignments took place that placed them into a position leading them to aviation higher education.

Professional pilot educators appeared to depart from previously discovered attributes about faculty at large. Finkelstein (1984) found that the choice to enter academia typically occurs in the graduate education arena but many decide while still involved in undergraduate education. Although professional 
pilot educators seemed to pick their path towards aviation either early in life or at least close to their college years, there was little, if any, interest in higher education until later in their lives.

Finally, it was interest of to the researcher to see what archetypes were identified that Reybold (2003) might apply to professional pilot faculty. Only one faculty appeared to be in line with the pilgrim model, which follows a "carefully planned path" (Reybold, 2003, p. 244). Another faculty could be identified as a visionary which "characterize their future faculty position, particularly their teaching and research roles, as a forum for achieving social change or educational reform." (Reybold, 2003, p. 245). The remainder of the interviewed faculty were best described by the drifter model which "expresses no singular commitment to academe [...] their odyssey may take them through the professoriate at some point in their professional migration, but it may just as well lead to a corporate position" (Reybold, 2003, p. 248).

\section{DISCUSSION}

The primary goal of this study was to investigate the motivations and influences behind the pursuit of aviation faculty careers. The findings of this study successfully allowed for the reaching of these research goals. The interviews conducted during this study were able to identify the motivations and influences that shaped the selection of professional pilot higher education as a career among a cohort of faculty. An equal number of individuals from the previously identified primary pathways (military and non-military) were queried so as to collect a balanced insight into such motivations and influences. The similarities and the differences between these groups further improved the characteristic profiles of all types of professional pilot faculty to include the internal and external factors that shaped their career choices.

Interview responses provided a detailed look into occupational and educational histories. Civilian faculty reported having a wide range of occupations on their path to the professoriate. Flying was clearly an overwhelmingly common thread in such occupational histories. Flight experience averaged more than 32 years. Time in aviation higher education was lengthy as well, with the average of 16 years. The career paths of military faculty were much more structured and succinct. All interviewed military faculty entered the military directly after completing college. These individuals progressed through their military careers through a range of flying and managerial positions. Only one individual was a "hybrid" where the individual entered the civilian flying world between their military service and entering postsecondary professional pilot education. The flight experience among these faculty averaged 33 years. The average length of time these military faculty have been in aviation higher education was five and a half years.

The educational histories of both civilian and military faculty were disparate. Subject areas in which faculty received their degrees were scattered across education, flying, engineering, and business-oriented subjects. Military faculty appeared to have followed the expected progression in degree attainment of those in the armed forces where they must seek advanced education in order to move up in rank. Civilian faculty pursued advanced education more for personal interests and for advancing their credentials for employment in industry and/or higher education.

A common trait among both groups of faculty was that their performance in undergraduate education was not as good as they would have liked it to be (with one exception) due to maturity or life-status issues. However, all faculty remarked that they excelled at higher levels of educational attainment. All faculty were first exposed to education through involvement in flight instruction yet the actual decision to go into aviation higher education was different for most of those interviewed. Two military faculty did seem to be set on seeking entrance into the profession early on, but the others either fell into the profession, or took a more traditional academic route. All faculty reported that they took some kind of action to position themselves more adequately to enter the teaching world. Most commonly, these individuals sought additional credentials and education. 
Families did appear to play a part in influencing the career paths of both groups of faculty. All military faculty had fathers that had served in the military which influenced the decision to follow in their footsteps. There was no apparent relationship between the occupations of civilian faculty and their fathers. Mothers of faculty seemed to be more of an influence on the realization of the importance of education. All faculty came from middle class families though none came from what could be considered a "professional" household (e.g. doctor or lawyer parents). This contrasts with previous research on faculty. Also different was the education level of the fathers of aviation faculty, as these individuals did not conform with previous research on faculty in terms of achievement of advanced education. Other family members helped influence faculty in both groups to pursue aviation such as airplane rides with uncles and family trips on airplanes. Relatives also influenced a leaning towards higher education from relatives that were admired who were in education to visits of a college campus where a relative worked.

Almost all of the interviewed faculty mentioned that they had some kind of mentoring during their career progression. Some of this was more focused on the specific requirements that would be expected of them to enter higher education while others were more generally supportive in the pursuit of such a career. It was apparent that certain individuals in the pasts of faculty were big influences in the seeking of such a career. Without the critical inputs of these mentors, it would be hard to assure that faculty would have come to the same conclusions about wanting to enter aviation higher education. Only one faculty reported open opposition along this individual's career path while another received some questioning from peers about the logic behind the decision to enter aviation higher education.

There was solely one faculty member reported being unsatisfied with the decision to enter professional pilot education. The overwhelming sentiment, however, was faculty would follow the same or similar path to reach their positions again, if given the chance, though not all agreed that aviation higher education was technically their calling in life. Faculty did state that they might do some things differently though only one made it sound as though this change would have been to avoid aviation higher education. Others responded that they would better position themselves for the career through education or timing of entrance into the field.

\section{CONCLUSION}

This study successfully identified the motivations and influences that played a role in shaping the career paths of a cohort of professional pilot educators. These were discovered through the use of a semistructured interview based upon a literature review on human and career motivation theories. The findings were then coded and processed with the assistance of NVivo qualitative analysis software. Results were presented in a narrative format guided by the interview questions. The results from this component of the study were compared to previous related research on faculty.

It is important to note, however, that this study only scratches the surface in pursuit of identifying motivations and influences that shaped the career paths of aviation faculty. While certainly compelling, the findings of this study cannot fairly be generalized to the entire population.

In sum, the data provided by this study will be helpful to all types of aviation industry stakeholders, as well as a wide range of persons associated with higher education, as they seek to understand the professional pilot program faculty cohort. Optimistically, the findings of this study can serve as a guide to why individuals choose to enter aviation higher education which may assist in recruiting individuals into the field and insuring a constant supply of future faculty. This is made possible by improving the understanding of what individuals are most likely to enter the field and be satisfied with such a decision. Lastly, this information lays a foundation for improving retention of current aviation faculty through an improved understanding of their sentiment about their careers. 


\section{Suggestions for Future Research}

While this study provides an improved understanding of the motivation of and influences on aviation faculty in their pursuit of a career in the professoriate, more research is necessary to expand upon existing data. Suggestions for future research include:

1. Further interview-based research on the job satisfaction, occupational expectations, and sentiment about the role of being a post-secondary aviation educator should be conducted so as to better understand what compels individuals to enter and stay within this realm of higher education.

2. This study should be repeated, but on a broader scale, to include faculty at all types of institutions and in all aviation subject area specialties. This will allow for the identification of subtle differences between groups so as to further improve the understanding what motivates and influences faculty. 


\section{REFERENCES}

Althauser, R. \& Van Veen, K. (1995). An algorithm for identifying career lines from job history data. Journal of Mathematical Sociology, 20(2-3), 89-107.

Astin, H. S. (1984). The meaning of work in women's lives: A sociopsychological mode of career choice and work behavior. The Counseling Psychologist, 12(117), 117-126.

Austin, A. E. (2002). Preparing the next generation of faculty: Graduate school associalization to the academic career. The Journal of Higher Education, 73(1), 94-122.

Baldwin, R. G. \& Blackburn, R. T. (1981). The academic career as a developmental process: Implications for higher education. The Journal of Higher Education, 52(6), 598-614.

Baty, M. J. (1985). Selection criteria requirements and current qualifications of aviation faculty in higher education. (Doctoral dissertation, The University of Tennessee, 1985). Dissertation Abstracts International, 46, 3259.

Berg, B. L. (2007). Qualitative research methods for the social sciences (6 ${ }^{\text {th }}$ ed.). Boston: Pearson Education, Inc.

Brown, D. M. (2007) Quality indicators for collegiate professional pilot training programs: A Delphi study. Ph.D. dissertation, Oklahoma State University, United States -- Oklahoma. Retrieved March 16, 2008, from ProQuest Digital Dissertations database. (Publication No. AAT 3259590).

Bureau of Transportation Statistics. (2008). Air carrier traffic statistics. Retrieved September 20, 2009 from http://www.bts.gov/programs/airline_information/

air_carrier_traffic_statistics/airtraffic/annual/1981_present.html

Campbell, S. M. (2006) Career paths of women clinical laboratory scientists who have become higher education administrators. Ph.D. dissertation, The University of Nebraska - Lincoln, United States -Nebraska. Retrieved October 24, 2008, from Dissertations \& Theses at the University of Nebraska - Lincoln database. (Publication No. AAT 3213859).

Clark, B. R. (1987). The academic life: Small worlds, different worlds. Princeton, NJ: The Carnegie Foundation for the Advancement of Teaching.

Conley, V. M. (Summer 2005). Career paths for women faculty: Evidence from NSOPF:99. New Directions for Higher Education, 130, 25-39.

Creswell, J. W. (2003). Research design: Qualitative, quantitative, and mixed methods approaches ( $2^{\text {nd }}$ ed.). Thousand Oaks, CA: Sage Publications, Inc.

Cross, W. T. (1991). Pathway to the professoriate: The American Indian faculty pipeline. Journal of American Indian Education, 30(2), 13-24.

Dierberger, B. S. (1998) Determination of informed choice and pathways leading to selection of the Environmental Studies major. Ph.D. dissertation, The University of Nebraska - Lincoln, United States - Nebraska. Retrieved October 24, 2008, from Dissertations \& Theses at the University of Nebraska - Lincoln database. (Publication No. AAT 9912685). 
Dolezal, D. D. (1991). The development and validation of a criterion-referenced test for seventh-grade mathematics students. Ph.D. dissertation, The University of Nebraska -- Lincoln, United States -Nebraska. Retrieved June 24, 2008, from Dissertations \& Theses at University of Nebraska - Lincoln database. (Publication No. AAT 9211489).

Donoghue, J. A. (2008, June). Training for the pilot shortage. AerosafetyWorld, 3(6), $41-44$.

Echaore-McDavid, S. (2005). Career opportunities in aviation and the aerospace industry. New York: Checkmark Books.

Elit, L. \& Otchet, F. (1999). Development of a population survey concerning Papanicolaou smear screening for cervical disease. Journal of Lower Genital Tract Disease, 3(1), 25-29.

Federal Aviation Administration. (2009). Administrator's fact book 2009. Retrieved September 20, 2009 from http://www.faa.gov/about/office_org/ headquarters_offices/aba/admin_factbook/media/200908.pdf

Federal Aviation Administration. (2001). Administrator's fact book 2001. Retrieved September 20, $2009 \mathrm{http}: / / \mathrm{www}$. faa.gov/about/office org/ headquarters_offices/aba/admin_factbook/media/200101.pdf

Ferony, A. I. (1996). A grounded theory investigation of why adults choose teaching as a later vocation. Ph.D. dissertation, The University of Nebraska - Lincoln, United States - Nebraska. Retrieved September 5, 2008 from Dissertation \& Theses at University of Nebraska - Lincoln database. (Publication No. AAT 9715962).

Finch, M., Begley, A., Sutherland, R., Harrison, M., \& Collins, C. (2007). Development and reproducibility of a tool to assess school food-purchasing practices and lifestyle habits of Australian primary school-aged children. Nutrition \& Dietetics, 64, 86-92.

Finkelstein, M. J. (1984). The American academic profession: A synthesis of social scientific inquiry since World War II. Columbus, OH: The Ohio State University Press.

Finley, B. L., Iannuzzi, T. J., Wilson, N. D., Kinnell, J.C., Craven, V. A., Lemeshow, S. (2003). The Passaic River creel/angler survey: Expert panel review, findings, and recommendations. Human and Ecological Risk Assessment 9(3), 829-855.

Fleet, C. M., Rosser, M. F., Zufall, R. A., Pratt, M. C., Feldman, T. S., \& Lemons, P. P. (2006). Hiring criteria in biology departments of academic institutions. BioScience, 56(5), 430-436.

Gay , L. R. \& Airasian, P. (2000). Educational research: Competencies for analysis and application (6 ${ }^{\text {th }}$ ed.). Upper Saddle River, NJ: Prentice-Hall, Inc.

Giacobbi, Jr., P. R. (2002). Survey construction and analysis, part I: How to conceptualize and design a survey. Athletic Therapy Today, 7(4), 42-44.

Hansen, J. S., \& Oster, Jr., C. V. (Eds.). (1997). Taking flight: Education and training for aviation careers. Washington, DC: National Academy Press.

Higher Education Research Institute. (2004). 2004 Faculty Survey. Los Angeles: Author. 
Holland, J. L. (1997). Making vocational choices: A theory of vocational personalities and work environments ( $3^{\text {rd }}$ ed.). Lutz, FL: Psychological Assessment Resources, Inc.

Holland, J. L. \& Gottfredson, G. D. (1976). Using a typology of persons and environments to explain careers: Some extensions and clarifications. Journal of Counseling Psychology, 22, 411-422.

Horrace, C. M. (1989). A profile of prevalent factors influencing adults to make career transitions into education. Ph.D. dissertation, The University of Nebraska Lincoln, United States - Nebraska. Retrieved September 5, 2008, from Dissertations \& Theses at University of Nebraska - Lincoln database. (Publication No. AAT 9004678).

Ison, D. C. (2009). Pathways to the Aviation Professoriate: An Investigation into the Attributes and Backgrounds of Professional Pilot Education Faculty. Collegiate Aviation Review, 27 (1).

Johns Hopkins University. (n.d.). Occupational personality types. Retrieved September 15, 2008 from http://hrnt.jhu.edu/cmp/RIASECtypes.cfm

Johnson, J. A. (1999). An examination of the U.S. collegiate aviation workforce in preparing the next generation aviation faculty members beyond 2000. Collegiate Aviation Review, 17(1), 31-39.

Kvale, S. (1996). InterViews: An introduction to qualitative research interviewing. Thousand Oaks, CA: Sage Publications.

Lindholm, J. A. (2004). Pathways to the professoriate: The role of self, others, and environment in shaping academic career aspirations. The Journal of Higher Education, 75(6), 603-635.

Maslow, A. H. (1954). The instinctoid nature of basic needs. Journal of Personality,22(3), 326-348.

Maslow, A. H. (1948). Some basic theoretical consequences of basic need-gratification. Journal of Personality, 16(4), 402-416.

Masse, L. C., Ainsworth, B. E., Totolero, S., Levin, S., Fulton, J. E., Henderson, K. A., \& Mayo, K. (1998). Measuring physical activity in midlife, older, and minority women: Issues from an expert panel. Journal of Women's Health, 7(1), 57-67.

Mitchell, L. K. \& Krumboltz, J. D. (1990). Social learning: Approach to career decision making: Krumboltz's Theory. In D. Brown \& L. Brooks (Eds.), Career choice and development ( $2^{\text {nd }}$ ed.) (145196). San Francisco: Jossey-Bass Publishers.

National Center for Education Statistics. (2006). 2004 National Study of PostsecondaryFaculty (NSOPF:04) methodology report - Technical report. Washington, DC: Author.

Prochaska-Cue, M. K. (1988) PIFS: Prochaska-Cue Inventory of Personal Financial Management Style. Ph.D. dissertation, The University of Nebraska Lincoln, United States -Nebraska. Retrieved June 24, 2008, from Dissertations \& Theses at University of Nebraska Lincoln database. (Publication No. AAT 9019581).

QSR International. (2008). NVivo 8.0 [computer software]. Cambridge, MA: Author.

Reybold, L. E. (2003, Summer). Pathways to the professoriate: The development of faculty identity in education. Innovative Higher Education, 27(4). 235-252. 
Reynolds, R. J., McCullough, J. D., Bendixen-Noe, M., \& Morrow, L. E. (1994). The need for knowledge about teacher educators. Willimantic, CT: Eastern Connecticut State University Department of Education.

Robinson, S., Murrells, T., \& Marsland, L. (1997). Constructing career pathways in nursing: some issues for research and policy. Journal of Advanced Nursing, 25, 602-614.

Roe, A. \& Lunneborg, P. (1990). Personality development and career choice. In D. Brown \& L. Brooks (Eds.), Career choice and development ( $2^{\text {nd }}$ ed.) (68-101). San Francisco: Jossey-Bass Publishers.

Ross, R. (2009). Pilots in a changing industry. Retrieved September 20, 2009 from http://www.erau.edu/er/hotcareers/pilot.html

Super, D. E. (1973). A theory of vocational development. In B. Eiduson \& L. Beckman (Eds.) Science as a career choice: Theoretical and empirical studies. New York: Russell Sage Foundation.

Weinrach, S. G. \& Srebalus, D. J. (1990). Holland's Theory of Careers. In D. Brown \& L. Brooks (Eds.), Career choice and development ( $2^{\text {nd }}$ ed.) (37-67). San Francisco: Jossey-Bass Publishers.

Wilson, L. (1942). The academic man: A study in the sociology of a profession. New York: Oxford University Press. 